\title{
Serum Level of Vitamin C in a Sample of Egyptian Patients with Multiple Sclerosis
}

\author{
Asmaa Ibrahim, Taha K. Alloush, Yousry Abo Elnaga, Mohamed Hamdy*, Mohamed M. Fouad \\ Department of Neurology, Faculty of Medicine, Ain Shams University, Cairo, Egypt \\ Email: *mohamedhamdy_neuro2007@yahoo.com
}

How to cite this paper: Ibrahim, A., Alloush, T.K., Elnaga, Y.A., Hamdy, M. and Fouad, M.M. (2019) Serum Level of Vitamin $\mathrm{C}$ in a Sample of Egyptian Patients with Multiple Sclerosis. Neuroscience \& Medicine, 10, 398-406.

https://doi.org/10.4236/nm.2019.104029

Received: November 24, 2019

Accepted: December 24, 2019

Published: December 27, 2019

Copyright $\odot 2019$ by author(s) and Scientific Research Publishing Inc. This work is licensed under the Creative Commons Attribution-NonCommercial International License (CC BY-NC 4.0). http://creativecommons.org/licenses/by-nc/4.0/

\begin{abstract}
Background: Antioxidants such as vitamin $\mathrm{C}$ can eliminate free radicles responsible for oxidative stress. Objective: To assess the serum level of vitamin $\mathrm{C}$ in a sample of multiple sclerosis (MS) patients to investigate a possible role of vitamin C in the pathogenesis of MS. Subjects and Methods: Forty patients with MS and twenty healthy controls were included in this study. Vitamin C level was estimated for each participant. Results: Serum vitamin C levels were significantly lower among the patients (ranging from $0.28 \mathrm{mg} / \mathrm{dL}$ to $0.75 \mathrm{mg} / \mathrm{dL}$ with mean $0.47 \pm 0.14 \mathrm{mg} / \mathrm{dL}$ and median of $0.46 \mathrm{mg} / \mathrm{dL}$ ) compared to controls (ranging from $0.60 \mathrm{mg} / \mathrm{dL}$ to $2.90 \mathrm{mg} / \mathrm{dL}$ with mean $1.87 \pm 0.61 \mathrm{mg} / \mathrm{dL}$ and median of $1.90 \mathrm{mg} / \mathrm{dL})(\mathrm{P}<0.001)$. A positive correlation was detected between age and serum vitamin $\mathrm{C}(\mathrm{r}=0.312, \mathrm{P}=0.049)$. Patients with infratentorial lesions had significantly lower levels of serum vitamin $\mathrm{C}$ compared to those who did not have infratentorial lesions $(\mathrm{P}=0.017)$. Conclusion: Patients with MS tended to have low serum vitamin $\mathrm{C}$ levels, and younger patients had lower serum levels.
\end{abstract}

\section{Keywords}

Vitamin C, Multiple Sclerosis

\section{Introduction}

Free radicals are mainly derived from oxygen (reactive oxygen species/ROS) and nitrogen (reactive nitrogen species/RNS), and are generated in response to various endogenous systems, exposure to different physicochemical conditions or pathophysiological states [1]. Overproduction of ROS (arising either from mitochondrial electron-transport chain or excessive stimulation of NADPH) results in oxidative stress, which in turn mediates damage of cell structures such as lipids, proteins, cell membranes and DNA [2]. 
There is significant evidence that the pathogenesis of several neurological diseases, including MS, may involve the generation of free radicals ROS and/or RNS associated with mitochondrial dysfunction [3]. ROS lead to oxidative stress and in turn have been implicated as mediators of demyelination and axonal damage in the experimental autoimmune encephalomyelitis. ROS cause damage to cardinal cellular components such as lipids, proteins and nucleic acids with subsequent cell death by necrosis or apoptosis. In addition, weakened cellular antioxidant defense systems and its vulnerability to ROS effects may increase damage [4].

A balance between free radicals and antioxidants is necessary for proper physiological function. If free radicals overwhelm the body's ability to regulate them, a condition known as oxidative stress is induced. Therefore antioxidants can assist in coping with this oxidative stress [5].

Vitamin $\mathrm{C}$ is one of the known protective antioxidant mechanisms [1]. This may postulate a possible role for vitamin $\mathrm{C}$, which is an important antioxidant for elimination of free radicles, in the pathogenesis of multiple sclerosis (MS). Deficiency of vitamin C, in turn, may play role in the pathogenesis of MS. The blood of patients with MS shows the signs of a significant oxidative stress manifested by low levels of some of the antioxidants [6] [7].

This study aimed to detect the serum levels of vitamin C in an Egyptian sample of patients with MS in order to investigate a potential role of vitamin $\mathrm{C}$ as an antioxidant in the pathogenesis of MS.

\section{Patients and Methods}

This was a case control study observational study that was conducted at Ain Shams University hospitals. The patients group included 40 patients with the diagnosis of MS, either relapsing remittent or secondary progressive, according to revised McDonald criteria 2010 [8]. Relapsing remittent MS (RRMS) patients had evidence of dissemination of space and time either clinically or based on magnetic resonance imaging (MRI). Secondary progressive MS (SPMS) patients had evidence of disability progression for one year at least. Patients were included if their age ranged from 18 to 60 years. Patients were excluded if comorbid hepatic, renal or malabsorption diseases, also patients who received corticosteroids during the last month before recruitment in the study were excluded. The control group included 20 healthy, age-matched and sex-matched individuals. Patients were recruited consecutively after their agreement to participate in the study. Expanded disability status scale (EDSS) scoring and MRI of brain and spinal cord (cervical and dorsal) were done for all the patients immediately after enrollment in the study. All blood donors gave their written informed consent to this study. At the time of blood withdrawal, neither patients nor controls were receiving any vitamin $\mathrm{C}$ supplementation for the past 6 months. The protocol of this study was approved by the ethical committee of Faculty of medicine at Ain Shams University. 
The blood samples were centrifuged at $2000 \times$ for 15 minutes, and then serum was obtained and stored at $-70^{\circ} \mathrm{C}$. For the quantitative detection of vitamin $\mathrm{C}$, vitamin C ELISA kit provided by ASSAY Kit Co., Ltd. was used and the instructions were done according to the provided catalogue. The values of serum vitamin $C$ from patients and controls were noted in the laboratory of Ain Shams University Hospitals.

The collected data of the present study was coded, tabulated, and statistically analyzed using Statistical Package for Social Sciences (SPSS ${ }^{\circledast}$ ); software program version 17.0. Descriptive statistics for numerical parametric data was presented as mean and standard deviation, and minimum \& maximum of the range. For numerical non-parametric ones, median and $1^{\text {st }} \& 3^{\text {rd }}$ inter-quartile ranges were presented. Dichotomous or categorical data were presented as number and percentage. Inferential analyses were done for quantitative variables using independent t-test and ANOVA-test, in cases of two independent groups and more than two groups respectively with parametric data, and Mann Whitney's U-test and Kruskal-Wallis in cases of two independent groups and more than two groups respectively with non-parametric data. For qualitative data, Chi square test for independent groups were used. The level of significance was set at a $\mathrm{P}$ value of less than 0.05 .

\section{Results}

Analysis of the demographic data showed that the case group included 10 males (25\%) and 30 females (75\%), and their age ranged from 20 to 57 years with mean age of $32.53 \pm 9.31$. The control group included 5 males $(25 \%)$ and 15 females $(75 \%)$, and their age ranged from 22 to 60 years with mean age of $33.10 \pm 10.50$. The comparison between the 2 groups revealed no statistical significance as regard to age and gender $(\mathrm{P}=0.830$ and $\mathrm{P}=1.000$ respectively).

The case group included 28 patients with the diagnosis RRMS (representing $70 \%$ of case group) and 12 patients with SPMS (representing 30\% of case group). Table 1 showed the clinical characteristics of the case group.

As regards the MRI findings among the case group, Table 2 illustrated the location and number of T2 lesions. All of the patients had periventricular lesions, while 38 patients had juxtacortical lesions, 31 patients had infratentorial lesions and 33 patients had spinal cord lesions.

Analysis of the laboratory data showed that serum vitamin C levels were

Table 1. Clinical characteristics of case group.

\begin{tabular}{cccc}
\hline Characteristics & All patients & RRMS & SPMS \\
\hline $\begin{array}{c}\text { Number of patients (\%) } \\
\text { Age of patient at onset of disease (years) } \\
\text { (mean } \pm \text { SD) }\end{array}$ & 40 & $28(70.0 \%)$ & $12(30.0 \%)$ \\
Duration of illness (years) (mean \pm SD) & $6.28 \pm 5.08$ & $7.14 \pm 4.83$ & $12.81 \pm 6.22$ \\
EDSS [range, median (IQR)] & $1-7.5,4.5(2-6)$ & $1-6,3(2-4)$ & $6-7.5,6.5(6-7)$ \\
\hline
\end{tabular}


significantly lower in the case group ranging from $0.28 \mathrm{mg} / \mathrm{dL}$ to $0.75 \mathrm{mg} / \mathrm{dL}$ with mean $0.47 \pm 0.14 \mathrm{mg} / \mathrm{dL}$ and median of $0.46 \mathrm{mg} / \mathrm{dL}$, when compared to control group ranging from $0.60 \mathrm{mg} / \mathrm{dL}$ to $2.90 \mathrm{mg} / \mathrm{dL}$ with mean $1.87 \pm 0.61$ $\mathrm{mg} / \mathrm{dL}$ and median of $1.90 \mathrm{mg} / \mathrm{dL}(\mathrm{P}<0.001)$ (Table 3 ).

The correlation between the demographics and clinical characteristics of the case group and serum vitamin $\mathrm{C}$ levels showed a positive correlation between age and serum vitamin $C(r=0.312, P=0.049)$ (Figure 1$)$, while no correlation was detected between serum vitamin $C$ and gender $(P=0.092)$, the age of the patient at the onset of disease $(P=0.125)$, the duration of illness $(P=0.328)$, and the EDSS score $(\mathrm{P}=0.203)$.

The comparison of vitamin C levels among RRMS and SPMS patients showed non-significant difference $(\mathrm{P}=0.959)$ (Table 4$)$.

As regards the MRI findings, there was a significant correlation between the serum levels of vitamin $C$ and the infratentorial lesions $(P=0.017)$ as patients with infratentorial lesions ranging from 1 - 5 lesions had significantly lower levels

Table 2. MRI characteristics of case group.

\begin{tabular}{|c|c|c|}
\hline \multicolumn{2}{|l|}{ Characteristics } & \multirow{2}{*}{$\begin{array}{c}\text { All patients }(\mathrm{n}=40) \\
19(47.5 \%)\end{array}$} \\
\hline \multirow{3}{*}{ Total number of brain $\mathrm{T} 2$ lesions } & $1-5$ & \\
\hline & $6-10$ & $12(30.0 \%)$ \\
\hline & $>10$ & $9(22.5 \%)$ \\
\hline \multirow{4}{*}{ Number of periventricular lesions } & Zero & $0(0.0 \%)$ \\
\hline & $1-5$ & $18(45.0 \%)$ \\
\hline & $6-10$ & $13(32.5 \%)$ \\
\hline & $>10$ & $9(22.5 \%)$ \\
\hline \multirow{4}{*}{ Number of juxtacortical lesions } & Zero & $2(5.0 \%)$ \\
\hline & $1-5$ & $20(50.0 \%)$ \\
\hline & $6-10$ & $11(27.5 \%)$ \\
\hline & $>10$ & $7(17.5 \%)$ \\
\hline \multirow{4}{*}{ Number of infratentorial lesions } & Zero & $9(22.5 \%)$ \\
\hline & $1-5$ & $30(75.0 \%)$ \\
\hline & $6-10$ & $1(2.5 \%)$ \\
\hline & $>10$ & $0(0.0 \%)$ \\
\hline Presence of spinal cord le & & $33(82.5 \%)$ \\
\hline
\end{tabular}

Table 3. Comparison between cases and controls regarding serum vitamin C level.

\begin{tabular}{cccc}
\hline Serum vitamin C level $(\mathrm{mg} / \mathrm{dL})$ & Cases $(\mathrm{n}=40)$ & Controls $(\mathrm{n}=20)$ & $\mathrm{P}$ \\
\hline Range & $0.28-0.75$ & $0.60-2.90$ & \\
Mean \pm SD & $0.47 \pm 0.14$ & $1.87 \pm 0.61$ & $<0.001$ \\
Median & 0.46 & 1.90 & \\
\hline
\end{tabular}




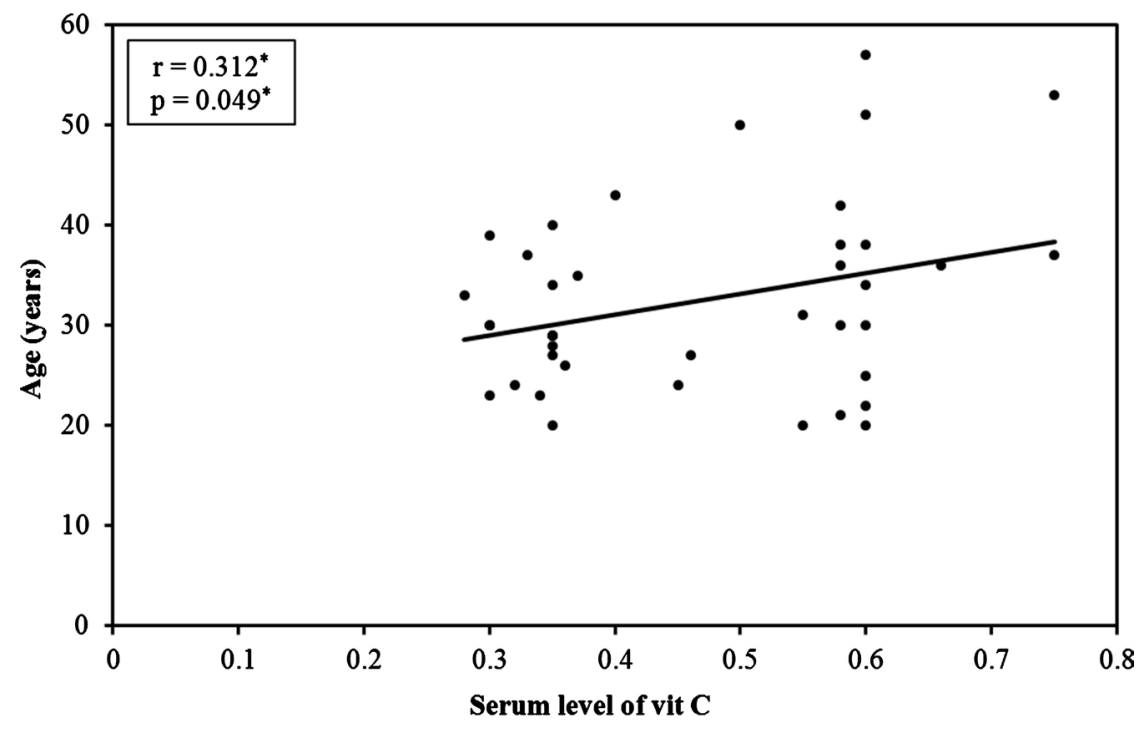

Figure 1. Correlation between age and serum level of vitamin $\mathrm{C}$ in case group.

Table 4. Comparison between serum vitamin C level in RRMS and SPMS patients.

\begin{tabular}{cccc}
\hline Serum vitamin C level $(\mathrm{mg} / \mathrm{dL})$ & RRMS $(\mathrm{n}=28)$ & SPMS $(\mathrm{n}=12)$ & $\mathrm{P}$ \\
\hline Range & $0.30-0.75$ & $0.28-0.60$ & \\
Mean \pm SD & $0.46 \pm 0.11$ & $0.47 \pm 0.18$ & 0.959 \\
Median & 0.46 & 0.48 & \\
\hline
\end{tabular}

of serum vitamin C (ranging from $0.28 \mathrm{mg} / \mathrm{dL}$ to $0.66 \mathrm{mg} / \mathrm{dL}$ with a mean value of $0.44 \pm 0.13 \mathrm{mg} / \mathrm{dL}$ and median of $0.37 \mathrm{mg} / \mathrm{dL}$ ) compared to those who did not have infratentorial lesions (ranging from $0.35 \mathrm{mg} / \mathrm{dL}$ to $0.75 \mathrm{mg} / \mathrm{dL}$ with a mean value of $0.57 \pm 0.13 \mathrm{mg} / \mathrm{dL}$ and median of $0.58 \mathrm{mg} / \mathrm{dL}$ ). There were no significant correlations between serum levels of vitamin $\mathrm{C}$ and the total number of $\mathrm{T} 2$ lesions $(P=0.891)$, number of periventricular lesions $(P=0.972)$, number of juxtacortical lesions $(P=0.593)$, or presence of spinal cord lesions $(P=0.309)$ (Table 5).

Table 5. Correlation between MRI characteristics and serum levels of vitamin C.

\begin{tabular}{|c|c|c|c|c|}
\hline \multirow{2}{*}{$\begin{array}{l}\text { Serum vitamin } \\
\text { C level (mg/dL) }\end{array}$} & \multicolumn{3}{|c|}{ Total number of $\mathrm{T} 2$ lesions } & \multirow{2}{*}{$\mathbf{P}$} \\
\hline & $1-5$ lesions $(n=19)$ & $6-10$ lesions $(n=12)$ & $>10$ lesions $(n=9)$ & \\
\hline Range & $0.28-0.70$ & $0.29-0.75$ & $0.34-0.62$ & \\
\hline Mean \pm SD & $0.48 \pm 0.19$ & $0.47 \pm 0.10$ & $0.47 \pm 0.16$ & 0.891 \\
\hline \multirow[t]{3}{*}{ Median } & 0.54 & 0.38 & 0.51 & \\
\hline & \multicolumn{3}{|c|}{ Periventricular lesions } & D \\
\hline & $1-5$ lesions $(n=18)$ & $6-10$ lesions $(n=13)$ & $>10$ lesions $(n=9)$ & \\
\hline Range & $0.28-0.75$ & $0.30-0.75$ & $0.32-0.60$ & \\
\hline Mean \pm SD & $0.49 \pm 0.15$ & $0.46 \pm 0.15$ & $0.47 \pm 0.13$ & 0.972 \\
\hline Median & 0.55 & 0.36 & 0.50 & \\
\hline
\end{tabular}




\section{Continued}

\begin{tabular}{|c|c|c|c|c|}
\hline \multirow{2}{*}{$\begin{array}{c}\text { Serum vitamin } C \\
\text { level }(\mathrm{mg} / \mathrm{dL})\end{array}$} & \multicolumn{3}{|c|}{ Juxtacortical lesions } & \multirow{2}{*}{$\mathbf{P}$} \\
\hline & $1-5$ lesions $(n=20)$ & $6-10$ lesions $(n=11)$ & $>10$ lesions $(n=7)$ & \\
\hline Range & $0.28-0.75$ & $0.30-0.75$ & $0.33-0.60$ & \\
\hline Mean \pm SD & $0.47 \pm 0.14$ & $0.48 \pm 0.16$ & $0.42 \pm 0.12$ & 0.593 \\
\hline \multirow[t]{3}{*}{ Median } & 0.46 & 0.50 & 0.35 & \\
\hline & \multicolumn{3}{|c|}{ Infratentorial lesions } & \multirow{2}{*}{$\mathbf{P}$} \\
\hline & \multicolumn{2}{|c|}{ No lesions $(n=9)$} & $1-5$ lesions $(n=30)$ & \\
\hline Range & $0.35-0.75$ & & $0.28-0.66$ & \\
\hline Mean \pm SD & $0.57 \pm 0.13$ & & $0.44 \pm 0.13$ & 0.017 \\
\hline \multirow[t]{3}{*}{ Median } & 0.58 & & 0.37 & \\
\hline & \multicolumn{3}{|c|}{ Infratentorial lesions } & \multirow{2}{*}{$\mathbf{P}$} \\
\hline & \multicolumn{2}{|c|}{ No lesions $(n=7)$} & $1-5$ lesions $(n=33)$ & \\
\hline Range & $0.28-0.66$ & & $0.30-0.75$ & \\
\hline Mean \pm SD & $0.42 \pm 0.15$ & & $0.48 \pm 0.14$ & 0.309 \\
\hline Median & 0.35 & & 0.50 & \\
\hline
\end{tabular}

\section{Discussion}

The results from this study showed that MS patients had significantly lower level of vitamin $\mathrm{C}$ compared to controls $(\mathrm{P}<0.001)$. Previous studies showed that MS patients had displayed significantly lower vitamin $\mathrm{C}$ level as compared to healthy individuals [9] [10]. Although we are convinced that vitamin deficiency alone is not an exclusive cause of MS, yet the relationship between vitamin deficiency and the pathogenesis of MS is still an area for research. For example vitamin D has been related to MS pathogenesis and disease progression in large cohorts and many studies [11] [12] [13]. As regards vitamin C we tried to investigate a possible role for vitamin $\mathrm{C}$ as an antioxidant in the etiology of MS. A more likely explanation for low vitamin C levels among MS patients in this study would be that vitamin $\mathrm{C}$ is consumed at an increased rate as defense mechanisms of the body against the ongoing oxidative stress. Other non-antioxidant function of vitamin $\mathrm{C}$ is inhibiting the binding of glutamate to the $N$-methyl-d-aspartate (NMDA) receptor, with subsequent prevention of excitotoxicity exerted by the glutamate [14].

Also the finding from this study and the above mentioned studies can support the pathogenesis of MS as imbalance between free radicals and antioxidants. This has to be validated in larger scales trials based on the results of this study and other previous studies [9] [10]. It worth to mention here that the possible role of dietary components in the pathogenesis of MS has been discovered in a similar way; reports from small trials that latter on were verified by larger multi-centered trials and cohorts, the same story as vitamin D.

One case-control study reported that higher intakes of ascorbic acid were ne- 
gatively associated with the risk of MS [15]. On the other hand, two large cohorts that examined the association between intake of dietary ascorbic acid and the risk of MS in women did not find associations between intakes of fruits and vegetables, use of ascorbic acid, or multivitamin supplements and the risk of MS [16].

In the present study there was there was positive correlation between age and serum levels of vitamin $\mathrm{C}$. This finding, if associated with the postulation that vitamin $\mathrm{C}$ is consumed at an increased rate against the ongoing oxidative burden, seems to be logical especially that the pathology of MS starts in the early stages of life, so vitamin $\mathrm{C}$ is early consumed among younger patients.

The serum levels of vitamin C did not correlate with the EDSS score or the types of MS (RRMS or SPMS). This was corroborated in previous study [9]. This may denote to a minimal role of vitamin $\mathrm{C}$ in the progression of the disease. This may postulate vitamin $\mathrm{C}$ might be related to the etiology of the disease rather than its progression.

As regards the MRI findings, patients with infratentorial lesions had significantly lower levels of serum vitamin $\mathrm{C}$ compared to those who did not have infratentorial lesions. Although infratentorial lesions are strongly correlated with disability [17], low vitamin C levels are not essentially related to disability as there was no correlation between serum level of vitamin C and EDSS scores.

The strengths of this study included the study design as a case control study, which allowed the comparison of the serum level of vitamin $C$ in the most common types of MS (RRMS and SPMS) to healthy controls. One of the limitations of this study may be the relatively small sized sample.

\section{Conclusion}

Patients with MS had lower serum vitamin C levels, compared to controls, and younger patients, had lower serum levels.

\section{Conflicts of Interest}

The authors declare no conflicts of interest regarding the publication of this paper.

\section{References}

[1] Devasagayam, T.P., Tilak, J.C., Boloor, K.K., Sane, K.S., Ghaskadbi, S.S. and Lele, R.D. (2004) Free Radicals and Antioxidants in Human Health: Current Status and Future Prospects. The Journal of the Association of Physicians of India, 52, 794-804.

[2] Valko, M., Leibfritz, D., Moncol, J., Cronin, M.T., Mazur, M. and Telser, J. (2007) Free Radicals and Antioxidants in Normal Physiological Functions and Human Disease. The International Journal of Biochemistry \& Cell Biology, 39, 44-84. https://doi.org/10.1016/j.biocel.2006.07.001

[3] Calabrese, V., Scapagnini, G., Ravagna, A., Bella, R., Foresti, R., Bates, T.E., Giuffrida Stella, A.M. and Pennisi, G. (2002) Nitric Oxide Synthase Is Present in the Cerebrospinal Fluid of Patients with Active Multiple Sclerosis and Is Associated with In- 
creases in Cerebrospinal Fluid Protein Nitrotyrosine and S-nitrosothiols and with Changes in Glutathione Levels. Journal of Neuroscience Research, 70, 580-587. https://doi.org/10.1002/jnr.10408

[4] Gilgun-Sherki, Y., Melamed, E. and Offen, D. (2004) The Role of Oxidative Stress in the Pathogenesis of Multiple Sclerosis: The Need for Effective Antioxidant Therapy. Journal of Neurology, 251, 261-268. https://doi.org/10.1007/s00415-004-0348-9

[5] Lobo, V., Patil, A., Phatak, A. and Chandra, N. (2010) Free Radicals, Antioxidants and Functional Foods: Impact on Human Health. Pharmacognosy Reviews, 4, 118-126. https://doi.org/10.4103/0973-7847.70902

[6] Syburra, C. and Passi, S. (1999) Oxidative Stress in Patients with Multiple Sclerosis. Ukrainskii Biokhimicheskii Zhurnal, 71, 112-115.

[7] Gironi, M., Borgiani, B., Mariani, E., Cursano, C., Mendozzi, L., Cavarretta, R., Saresella, M., Clerici, M., Comi, G., Rovaris, M. and Furlan, R. (2014) Oxidative Stress Is Differentially Present in Multiple Sclerosis Courses, Early Evident, and Unrelated to Treatment. Journal of Immunology Research, 2014, Article ID: 961863. https://doi.org/10.1155/2014/961863

[8] Polman, C.H., Reingold, S.C., Banwell, B., Clanet, M., Cohen, J.A., Filippi, M., Fujihara, K., Havrdova, E., Hutchinson, M., Kappos, L., Lublin, F.D., Montalban, X., O'Connor, P., Sandberg-Wollheim, M., Thompson, A.J., Waubant, E., Weinshenker, B. and Wolinsky, J.S. (2011) Diagnostic Criteria for Multiple Sclerosis: 2010 Revisions to the McDonald Criteria. Annals of Neurology, 69, 292-302. https://doi.org/10.1002/ana.22366

[9] Tavazzi, B., Batocchi, A.P., Amorini, A.M., Nociti, V., D’Urso, S., Longo, S., Gullotta, S., Picardi, M. and Lazzarino, G. (2011) Serum Metabolic Profile in Multiple Sclerosis Patients. Multiple Sclerosis International, 2011, 167156-167163. https://doi.org/10.1155/2011/167156

[10] Polachini, C.R., Spanevello, R.M., Zanini, D., Baldissarelli, J., Pereira, L.B., Schetinger, M.R., da Cruz, I.B., Assmann, C.E., Bagatini, M.D. and Morsch, V.M. (2016) Evaluation of Delta Aminolevulinic Dehydratase Activity, Oxidative Stress Biomarkers, and Vitamin D Levels in Patients with Multiple Sclerosis. Neurotoxicity Research, 29, 230-242. https://doi.org/10.1007/s12640-015-9584-2

[11] Munger, K.L., Hongell, K., Åivo, J., Soilu-Hänninen, M., Surcel, H.M. and Ascherio, A. (2017) 25-Hydroxyvitamin D Deficiency and Risk of MS among Women in the Finnish Maternity Cohort. Neurology, 89, 1578-1583. https://doi.org/10.1212/WNL.0000000000004489

[12] Smolders, J., Menheere, P., Kessels, A., Damoiseaux, J. and Hupperts, R. (2008) Association of Vitamin D Metabolite Levels with Relapse Rate and Disability in Multiple Sclerosis. Multiple Sclerosis, 14, 1220-1224. https://doi.org/10.1177/1352458508094399

[13] Munger, K.L., Levin, L.I., Hollis, B.W., Howard, N.S. and Ascherio, A. (2006) Serum 25-Hydroxyvitamin D Levels and Risk of Multiple Sclerosis. JAMA, 296, 2832-2838. https://doi.org/10.1001/jama.296.23.2832

[14] Harrison, F.E. and May, J.M. (2009) Vitamin C Function in the Brain: Vital Role of the Ascorbate Transporter SVCT2. Free Radical Biology \& Medicine, 46, 719-730. https://doi.org/10.1016/j.freeradbiomed.2008.12.018

[15] Ghadirian, P., Jain, M., Ducic, S., Shatenstein, B. and Morisset, R. (1998) Nutritional Factors in the Aetiology of Multiple Sclerosis: A Case-Control Study in Montreal, Canada. International Journal of Epidemiology, 27, 845-852. https://doi.org/10.1093/ije/27.5.845 
[16] Zhang, S.M., Hernan, M.A., Olek, M.J., Spiegelman, D., Willett, W.C. and Ascherio, A. (2001) Intakes of Carotenoids, Vitamin C, and Vitamin E and MS Risk among Two Large Cohorts of Women. Neurology, 57, 75-80.

https://doi.org/10.1212/WNL.57.1.75

[17] Tintore, M., Rovira, A., Arrambide, G., Mitjana, R., Río, J., Auger, C., Nos, C., Edo, M.C., Castilló, J., Horga, A., Perez-Miralles, F., Huerga, E., Comabella, M., Sastre-Garriga, J. and Montalban, X. (2010) Brainstem Lesions in Clinically Isolated Syndromes. Neurology, 75, 1933-1938.

https://doi.org/10.1212/WNL.0b013e3181feb26f 